\title{
Becoming a "New" Museum? Contesting \\ Oceanic Visions at Musée du Quai Branly
}

Margaret Jolly

Viewed from the Seine, through its glass palisade, the museum looks like a capsized container ship ... in dry dock. Hoisted on pillars, the exhibition plateau seems exposed and incongruous. Red, grey, yellow windowless boxes protrude. Seen from the Rue de l'Université, on the opposite side, the long scored body seems already to be rusting. Three smaller buildings are yoked to one end; a domed restaurant perches on the top. Underneath, a garden, or rather a forest is taking root. The trees are small, anchored by stakes and wires, accompanied by thousands of seedlings and grasses whose irrigation tubes and valves haven't yet been made to vanish. When the surrounding forest has grown up, the museum will, according to its architect, mysteriously dematerialize. The colored boxes will be glimpsed as if they were native "huts" poking through jungle foliage.

- James Clifford, “Quai Branly in Process”

(SEE FIGURE I).

\section{Openings AND BECOMINGS}

These are the opening words of an evocative essay by James Clifford on Musée du Quai Branly as he witnessed it during the opening events of 20-25 June 2006. ${ }^{1}$ Like the green thicket growing on one of its outside walls, he saw the museum as in the process of becoming, housing not just a dark forest sequestering objects that spectators are invited to explore, but a jungle of "contradictions and tensions," a "coalition of different agendas" (2007, 3). Several years later, although the garden has matured and blossomed, the museum has neither dematerialized nor transmogri-

The Contemporary Pacific, Volume 23, Number I, I08-I39

(C) 20 I I by University of Hawai'i Press 


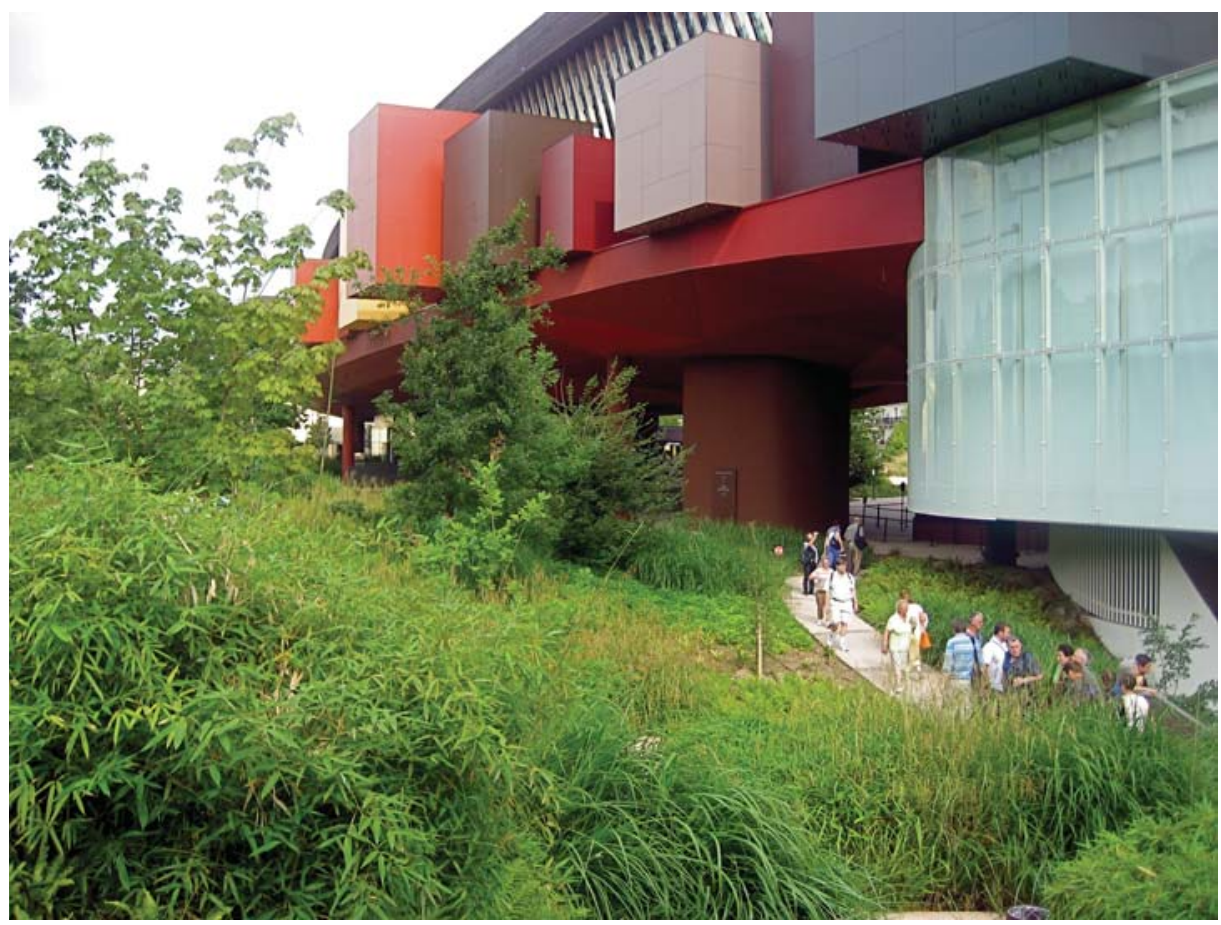

FIgURE I. The garden surrounding the Musée du Quai Branly, two years after the opening. June 2008. Photo courtesy of James Clifford.

fied into a series of native "huts." Tensions between rival visions of the museum persist but have also matured.

Musée du Quai Branly has generated passionate debates, even before its opening, engaging scholars, museum professionals, politicians, journalists, and publics in France as well as broader global audiences. In a recent article, Anthony Alan Shelton critically analyzed fifty reviews in both the francophone and anglophone press, asking whether $\mathrm{MQB}$ articulates "the last painful gasps of the old museum model" or a "new direction" (2009, I4). ${ }^{2}$ The newness envisaged for the "new museum" embraces not just novel museological practices but also a transformed cultural politics, challenging colonial hierarchies constructed between peoples and arts (Message 2006). In her book Paris Primitive (2007), Sally Price offered a devastating critique of the museum, suggesting that primitivist aestheticism prevailed over postcolonial pretensions to a space where "cultures converse." Her most recent reassessment (Price 20IO), though more muted, is still critical. Clifford articulated many cognate critical concerns in his 2007 essay but 
refused to foreclose on the museum's future, suggesting there were some signs of alternative visions. Here I reflect on their divergent views, primarily through the prism of Oceanic art from the Pacific and Indigenous Australia displayed in the permanent collections as well as in the fabric of the building. Then through the lens of a conference associated with the Polynésie/Pacific Encounters exhibition at the MQB in June 2008, I ponder the broader question of how Oceanic objects held in museums relate to the descendants of their creators and how objects are animated as subjects through the presence and performances of living Oceanic peoples.

\section{An Origin Story}

First let me relate the origin story of the $\mathrm{MQB}$ and consider its discursive genealogy: It begins with a meeting in Mauritius in I990, perhaps even a sunset encounter on the beach at the Royal Palm Hotel, between Jacques Chirac (then mayor of Paris) and Jacques Kerchache, "an influential collector and connoisseur of tribal art" (Clifford 2007, 8; Price 2007, I-3). In this primal scene, the two Jacques discover a common love of "les arts premiers" and resolve to consummate this love by moving some to the Louvre, to cohabit with the European masterpieces. ${ }^{3}$ In 2000, five years after Chirac becomes president, the Pavillon des Sessions opens with a hundred stunning sculptures "summoned to the Louvre" (Clifford 2007, 8) from the Musée de l'Homme and the Musée National des Arts d'Afrique et d'Océanie. Kerchache dies of throat cancer in Mexico in 200I, but this small gallery of exquisite exotic masterpieces remains a living testament to his influence. ${ }^{4}$

However, in Kerchache's wake, the turbulence around what "arts premiers" might mean intensified. As Price declared, this is "a conveniently ambiguous term ... translated variously as primal arts, remote arts, premier arts, first arts, primeval art, primordial art, or even-God forbidprimitive art" (2005, I34; see also Myers 2005a). ${ }^{5}$ The anthropologists "summoned to the Louvre"-Maurice Godelier, Lorenzo Brutti, and others-fought hard against Kercharche's curatorial strategy of highlighting the beauty of objects devoid of ethnography and history (see Godelier 2009). ${ }^{6}$ Brutti observed how, given a range of carbon-I 4 dates on individual artifacts, the earliest was usually chosen, likely the age of the material rather than the date of the object's creation (Brutti 2003, 2I-26; Brutti, pers comm, Feb 200I; Price 2007, 77). Moreover, Brutti documented how Kercharche's curatorial interpretations were often wildly different from 
Indigenous conceptions: “a European vision of a cock's comb symbolizing virility won the day over New Ireland understandings about a local bird symbolizing androgyny ... [and] the connoisseur's vision of a tender embrace of sensual lovers turned a blind eye to the natives' [Solomon Islanders'] vision of a murderous stranglehold by a malevolent spirit" (Price 2007, I76; see also Price 2007, 75-78).

The removal of these objects from two preexisting museums (the Musée de l'Homme and the Musée National des Arts d'Afrique et d'Océanie) to the Louvre and later to Quai Branly has been variously described as "looting" (Clifford 2007, 8), and "cannibalism"-vilifiers with distinctive martial and colonial echoes. ${ }^{7}$ The Pavillon des Sessions in the Louvre anticipated the way in which the new museum at Quai Branly was conceived: to eclipse the colonial inheritance of the older museums and their unfortunate associations with evolutionary science.

The Musée de l'Homme had opened in I 937 after the Paris World Fair. A monument to "socialist humanism" and "holistic human science" (Clifford 2007, 6), it combined the biological and cultural story of "man," creolizing evolutionary and universalist narratives. In its time its creators had also aspired to be "new," to eclipse the exoticism of the Musée d'Ethnographie du Trocadéro, with a novel emphasis on both research and theory in the new social sciences. Paul Rivet (director of its parent, the Musée National d'Histoire Naturelle) and George Henri-Rivière (its founding director) were strongly influenced by Marcel Mauss and Lucien Lévy-Bruhl. By the turn of the twenty-first century, the Musée de l'Homme was no doubt dusty, mismanaged, and neglected in state funding: it is now an "empty shell" (Clifford 2007, 7), a "melancholy corpse" (Shelton 2009, 2)..$^{8}$

Only 3,500 objects from Musée de l'Homme are on display at Quai Branly; most of the 250,000 artifacts were removed to underground storage on site. ${ }^{9}$ The future focus of Musée de l'Homme is envisaged as the physiological and biological aspects of humanity; it still houses human remains, including 35,000 human skulls. Claims for repatriation of such remains are fraught: witness the eventual removal, after protracted wrangling with the French government, of the remains of Saartjie Baartman (a Khoikhoi woman, the so-called "Hottentot Venus") to her final resting place in South Africa in 2002. There will likely be parallel painful negotiations in the future from which, it was perhaps hoped, Musée du Quai Branly could float free. But given the number of artifacts presently on display at $\mathrm{MQB}$ that include skulls—for example, the rambaramp funerary 


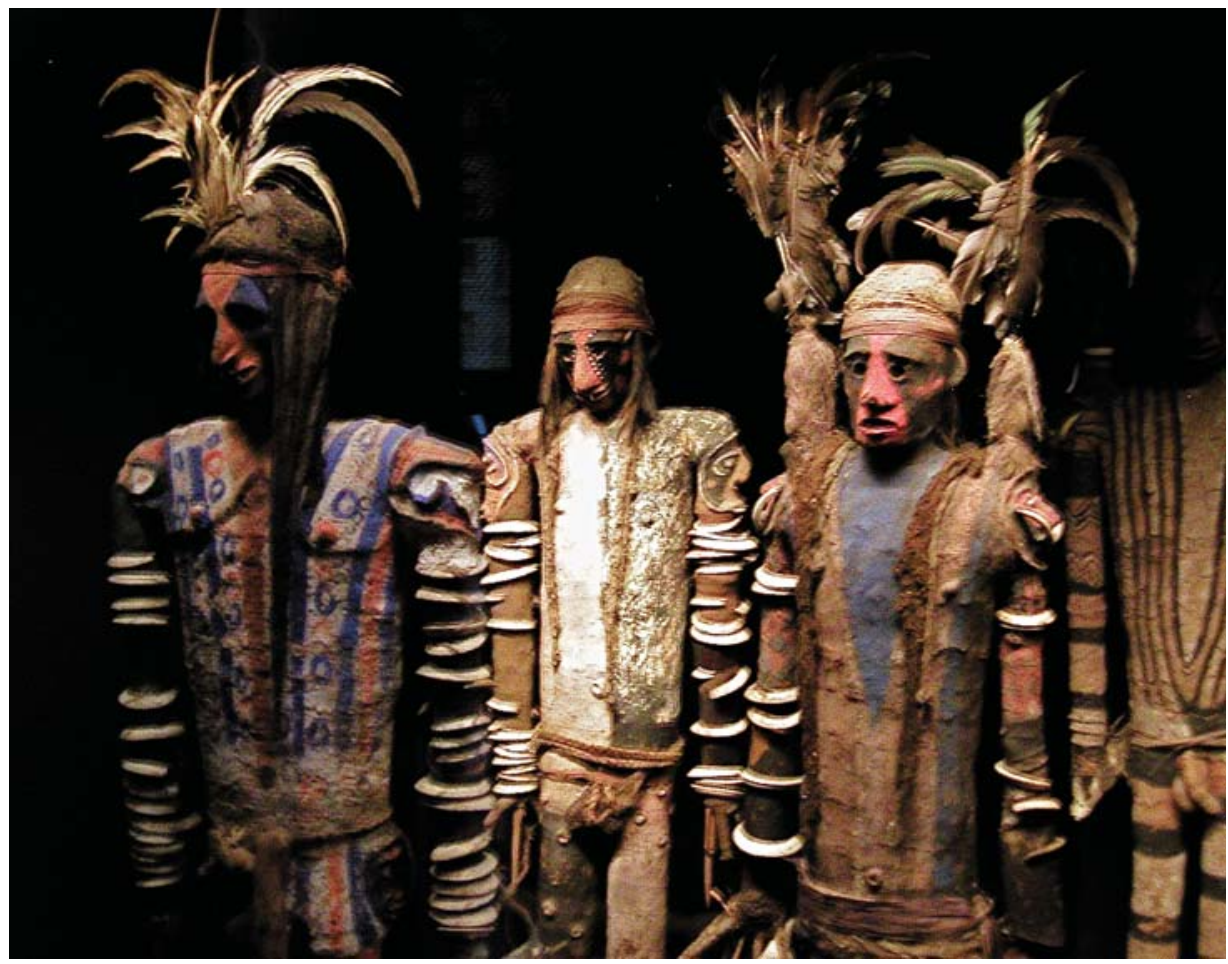

FIgURE 2. Rambaramp funerary effigies from Malakula, Vanuatu, in the MQB permanent collection. June 2006. Photo courtesy of James Clifford.

effigies of Malakula, Vanuatu (see figure 2); the reliquary-fish holding a skull from Santa Ana, Solomon Islands; and the skulls from the Asmat region of Papua (MQB 2006, 42, 56, 60-6I) - the potential for future claims for repatriation cannot be discounted. And, the French legislative environment concerning repatriation has dramatically altered in the last two years, as shown in the recent passage of a bill through the National Assembly related to the return of Māori heads, discussed later in this essay (see also note 35$).^{10}$

The other 25,000 objects moved into the new museum came from Musée National des Arts d'Afrique et d'Océanie (MNAAO), previously Musée des Colonies, created for the I93 I Colonial Exposition in the Palais des Colonies. The declaration of its colonial origins was unabashed in its first name, and although that name was later removed, the colonial perspective persists to the present in the reliefs by Alfred Janniot depicting "tall ships, lions, tigers and elephants among jungle palms and semi-naked 
Pacific, African and Asian peoples ... the tangle of trading ties between France and her colonies" (Naumann 2006, I I9). In the twenty-first century the future prospects for the Musée National des Arts d'Afrique et d'Océanie may prove even more difficult than for the erstwhile Musée de l'Homme, which reopened in June 2007 as La Cité National de l'Histoire d'Immigration. But when Sarkozy came to power and announced a new Ministry for Immigration and National Identity, two-thirds of the museum's twelve historical advisors resigned (Sauvage 2007, I 5 I). ${ }^{11}$

\section{"Where Cultures Converse"}

As many commentators have averred, Musée du Quai Branly is both physically and conceptually distanced from this colonial past, deflecting discomfiting questions about evolutionary theory and imperial appropriation with its stress on the aesthetics of the objects, "exemplary works ... of exceptional quality" (Naumann 2006, I I9). MQB combines an "aggressive aestheticism" with a transcendent and very French universalism. ${ }^{12}$ It is Chirac's monument, in the tradition of Georges Pompidou's Beaubourg and François Mitterrand's glass pyramid at the Louvre (by I M Pei)a presidential habit that Maurice Godelier once wryly described to me as "Pharaonic." This is not to deny the truth of the passion of Chirac's desire to pay respect to other cultures, nor the seriousness of the museum's motto: "Where Cultures Converse." But, we might wonder, why this reification of "cultures" talking? As both Clifford $(2007,5)$ and Price $(2007$, I69ff) astutely asked: who is speaking, in what languages, and with what authority? (See Digard 2008.) Are these conversations really framed by a new postcolonial egalité? (See Lebovics 2009.)

Both the building and the statements by its inaugural president, Stéphane Martin, are telling. Let me consider Martin's statements first. In a series of interviews and media statements he critiqued the "priests of contextualization" (Kimmelman 2006, 3) -presumably Godelier, Brutti, and others-affirming that the purpose of a museum "is making theater, not writing theory." Martin insisted, "Every European and French curator will start with the object" (Naumann 2006, I22), and he observed how the definition of a museum as a collection is enshrined in French law. $\mathrm{He}$ vigorously opposed what he considered undue contextual information and the didactic storytelling of "Anglo-Saxon" museums in North America and Australia, in telling stories about slavery or women's liberation, for instance. By contrast, he declared, "the French are obsessed by the purity 
and authenticity of the object" (Naumann 2006, I22). Yet elsewhere he opposed the search for cultural purity as an illusion. In conversation with Caroline Brothers of the New York Times, he proclaimed: "We eat Thai, our tattoos are Polynesian, we dress African and do our hair in Antillais style [the "we" is presumably modern Europeans]. . . . All that means that the notion of cultural purity on which former ethnological museums rested makes no sense today" (Brothers 2006). "Today" is presumably distinctively, even uniquely, global in its cultural mixing, as the erstwhile imperial metropolis appropriates the sartorial styles and engorges itself on the cuisines of other cultures. ${ }^{13}$

Jean Nouvel's building embodies this stress on the theatrics of the new French global. It is situated in an area of broad boulevards designed by Baron Haussmann and flanked by noble nineteenth-century apartments that were designed to cleanse "the old city of its medieval squalor" and to sequester the bourgeois from the threats of contagion from "the downtrodden urban populace, among whom radical ideas festered" (Ouroussoff 2006). Nouvel has disrupted the rational order of Haussmann with his anarchic design, "carelessly patched together" (Ouroussoff 2006), ${ }^{14}$ and the different facades-one rusty louvers, another punctuated with jutting boxes of "Crayola" colors (Kimmelman 2006), another a "hairy wall" of plants (Price 2007, I I9; see figure 3), and a surround of lush wild gardens. ${ }^{15}$ The entrances to the museum seem designed to be hard to find, while the darkened interior has been variously likened by the architect to a "sacred wood" or "a jungle." A long, white, curving ramp, framed by portentous rhetoric from Trinh Minh-Ha, evokes the limen of a rite of passage as we enter, with choreographed sounds and video images projected on its surfaces. ${ }^{16}$ It descends into the gloom of the "plateau des collections," immersing the spectator in a darkness from which the objects emerge, bathed in spotlights, stunning but enigmatic (see figure 4 ) ${ }^{17} \mathrm{We}$ follow Nouvel's river, an undulating channel formed from tan leather, along which the various regions of the non-European world are plotted and their objects distributed. The objects live in beautiful black cases, on floors stained black with contours of dark red. ${ }^{18}$ There is no sign of the dust of Musée de l'Homme; these objects are refreshed and gleaming, their beauty enhanced by artful high-tech lighting. ${ }^{19}$ Spectators are invited to become "explorers." Clifford deplored how, in the regions of "darkest Africa," "the literalism of Nouvel's neo-Naturvolker concept is especially oppressive" (2007, 10). ${ }^{20}$ 


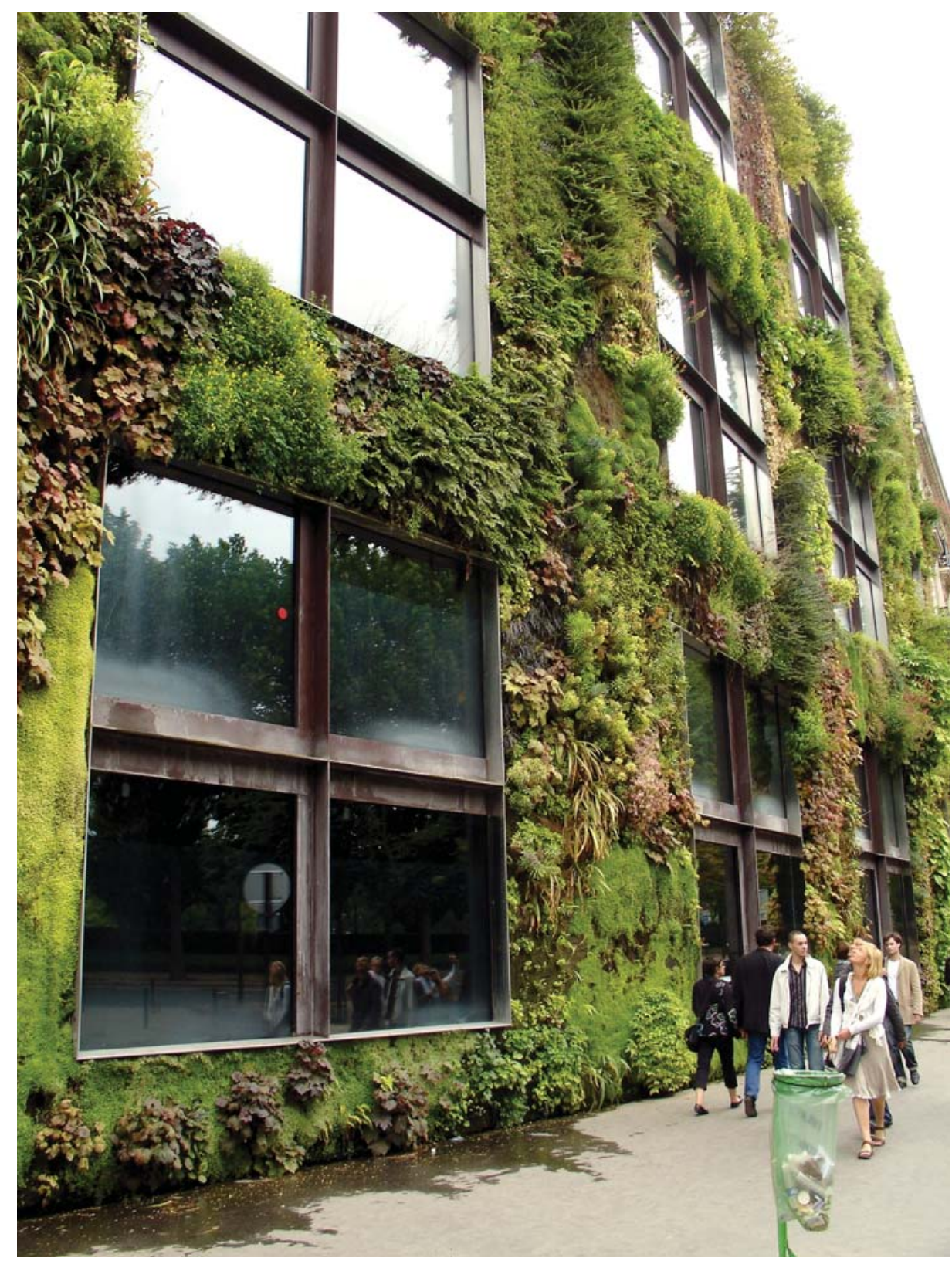

FIgURE 3. The "hairy wall" on the MQB administration building from the side of the Seine. 24 June 2007. Photo courtesy of Geoffrey White. 


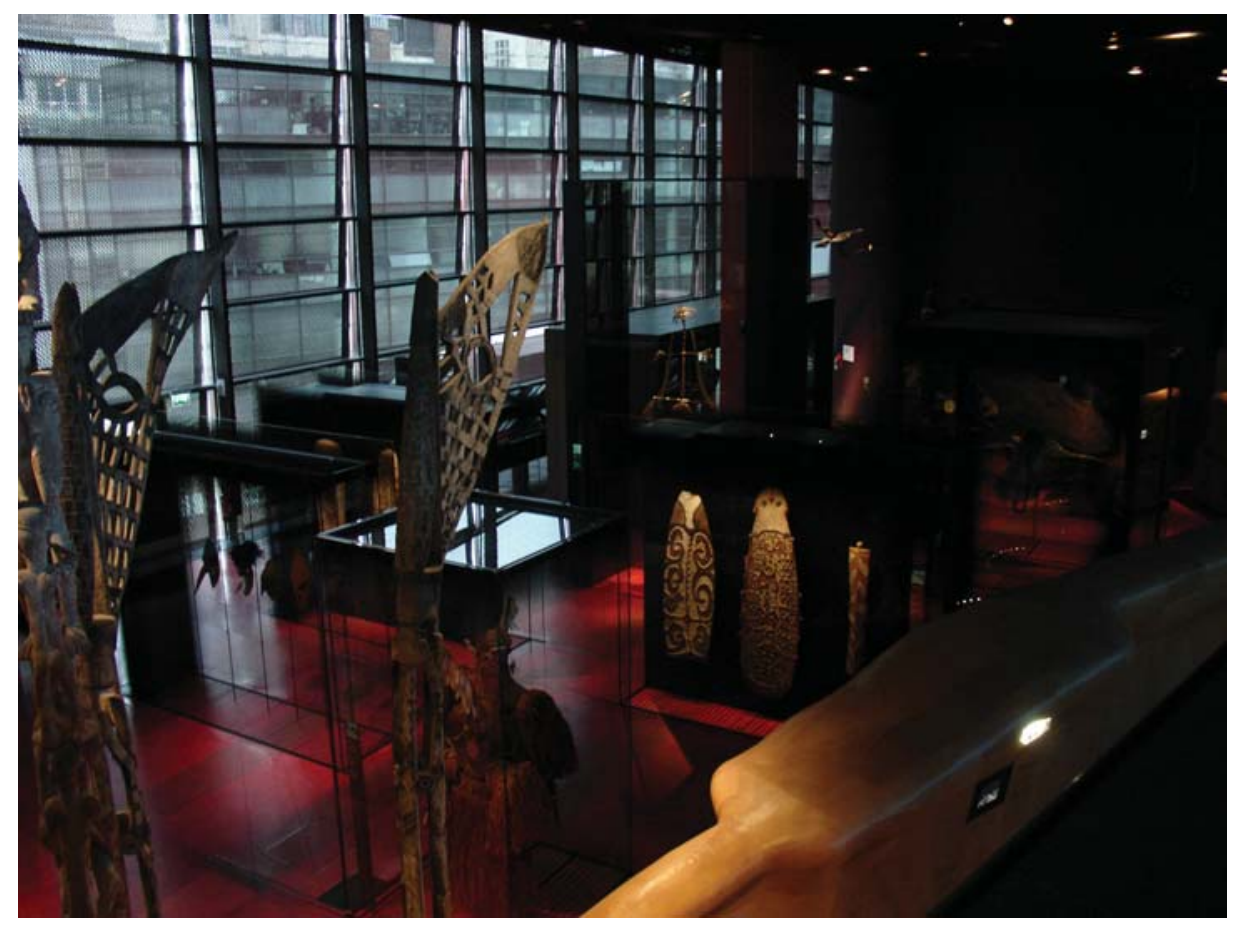

FIgure 4. The Oceanic section of the MQB permanent collection, viewed from above. 20 June 2007. Photo courtesy of Geoffrey White.

It also pervades "darkest Oceania," shrouded in a murky light through glass glazed over with images of rain forests and palm trees. This is somewhat relieved not so much by the clarifying windows of written labels (black on white and hard to connect to the encased objects) as by touchscreen videos showing sequences of ethnographic films, such as Robert Gardner's Dead Birds. In Clifford's view these offer some cultural context, with interviews and films showing practices in which the objects are used, affording a relieving realism. But these screens are disarticulated from the dominant aesthetic of inscrutable mysteries (Clifford 2007, I0). When Clifford was there, few people touched them or visited the "absorbing interactive installations" in the multimedia gallery upstairs (Clifford 2007, I3). On my several visits, with crowds of schoolchildren who were drawing some Oceanic objects as part of their lessons, these video screens were frequently touched but rarely watched for long. Like Price I found them quaintly archaic and absurdly small: "video screens whose dimensions would make a television set from the I940s look like a wide-screen 


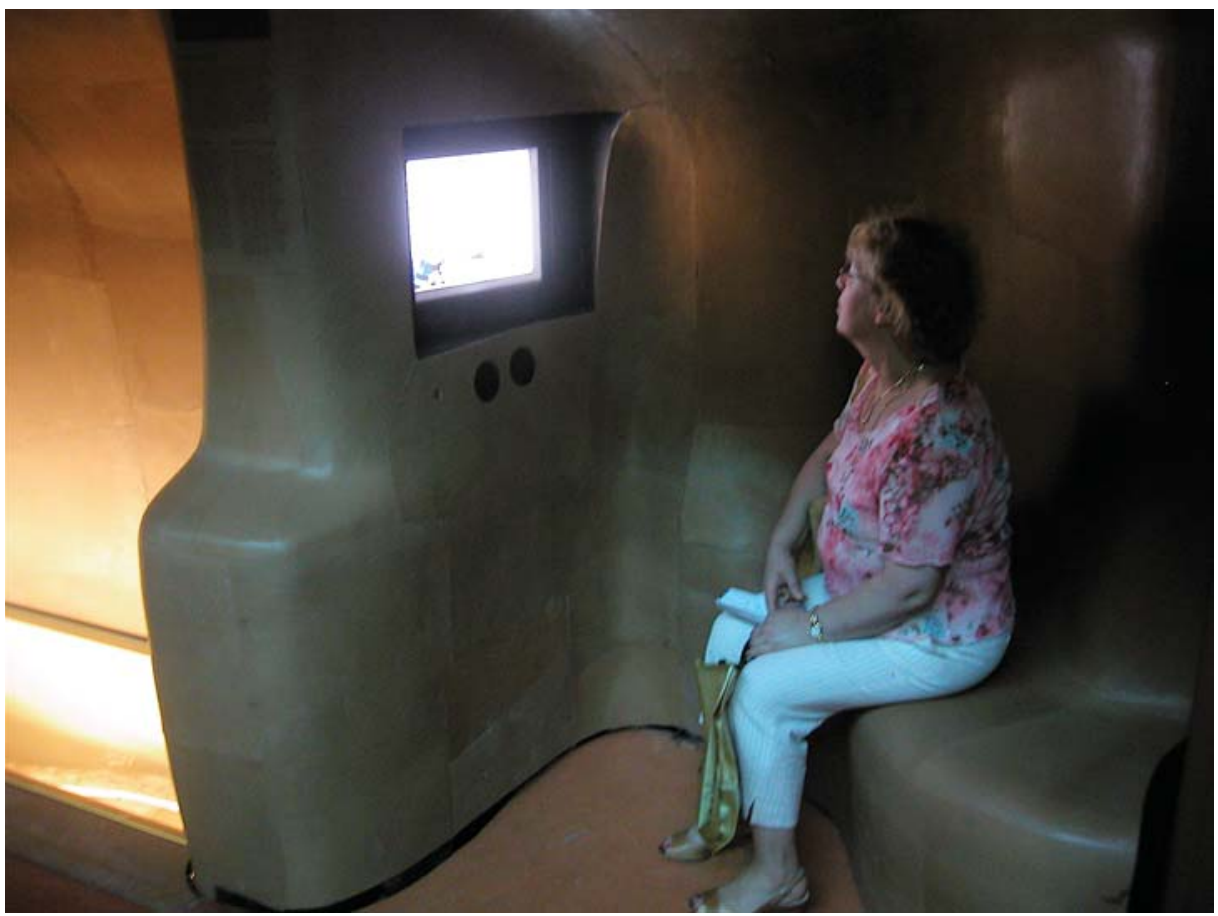

Figure 5. Small video screens embedded in Jean Nouvel's tan leather "river" in the Musée du Quai Branly. June 2006. Photo courtesy of James Clifford.

high-definition wonder by comparison" (Price 2007, I47; see figure 5). Presumably this was intentional, so as not to detract aesthetic attention from the objects.

Ultimately Clifford adjudged the permanent displays superficial and confusing. Michael Kimmelman, writing earlier in the New York Times, was even less generous, suggesting that the architectural design and dominant curatorial strategy stages a "heart of darkness" (Kimmelman 2006). ${ }^{21}$ He discerned a neo-imperial posture in assimilating diverse non-European peoples to "the other" and locating them in a jungle that resounds with echoes of the noble savage, closer to nature. In my view, aestheticism and exoticism triumph-in the presentation of the objects, the calculated disorientations of the building, the manufactured wild gardens, the vegetated walls, and the jungle within. Nouvel may be celebrating nature to Haussman's culture, but his twenty-first-century ecologism seems as problematic as eighteenth-century constructions of the state of nature. ${ }^{22}$

So, since the time of its opening, many salvos have been hurled at Musée 
du Quai Branly, in electronic and print media, in popular and scholarly genres. A book in French by Bernard Dupaigne (2006) and Sally Price's Paris Primitive (2007) articulate detailed and developed critical appraisals (see also Le Débat 2007). ${ }^{23}$ Some museum staff have fueled the fire, as in statements by Emmanuel Désveaux, anthropologist and scientific director of Musée du Quai Branly from 200I to 2005. He justified the "postcolonial" stress on the sheer beauty of the objects as a way of banishing the story of evolutionism. "I think that we better approach postcolonialism when we empty the museography of any narrative, either implicit or explicit, that is linked to evolutionism" (Désveaux, quoted in Sauvage 2007, I40). But despite the rhetorical avowal of the equality of peoples through the equality of arts, the narrative of colonial history and decolonization is also simultaneously emptied from the museum. The stress on aesthetics deflects any awkward questions about how the objects were collected. ${ }^{24}$ And, as Clifford suggested $(2007,5)$, it echoes how Jacques Chirac in his public rhetoric at the opening ceremonies "translated the language of neo-primitivism into the language of universal human rights."

Yet in Désveaux's view, the equality of peoples cannot extend to the recognition of Indigenous claims in control over objects or influence over curatorial questions. Désveaux is unequivocal: "Although we will take them into account, we do not think it is wise to construct a discourse on the collections that purely respond to Indigenous claims. They are unstable, rarely consistent and they collide with the present state of scientific knowledge. More than that, their ideological roots, however legitimate, tend to filter out the realities of history" (Désveaux 2002, quoted in Sauvage 2007, I45)—unlike French ideologies, which are perforce consistent with "scientific knowledge" and "the realities of history," it seems.

\section{EMBRACING INDIgENOUS Australians}

But how we can reconcile this statement, which summarily dispatches the "ideological" claims of Indigenous peoples as colliding with scientific knowledge, and the dominant curatorial emphasis on the enigmatic treasures of ancient or distant others, with the museum's embrace of contemporary art from Indigenous Australia-an embrace much celebrated in the Australian media as a sign of both recognition of the Antipodes and a new French multiculturalism? Aboriginal paintings from Karel Kupka's collection are included in the permanent exhibition, "the museum's only significant collection of contemporary art" (Naumann 2006, I I9), while 
eight contemporary Indigenous Australian artists were commissioned by Nouvel to create works to be an integral part of his building (see Armstrong 2006). ${ }^{25}$

Most of these are installed in the module dedicated to administration, research, and conservation. A painting by Lena Nyadbi, an artist from the Gija people of the East Kimberley region in Western Australia, has been rendered in the architecture of the façade on Rue de l'Université (although its black-on-white palette was reproduced in grey on grey and she was slow to give her approval, suggesting that the forms looked rather like sausages). ${ }^{26}$ Inside on several levels, reproduced as ceiling decorations, are oversized recreations of paintings by Gulumbu Yunupingu (Gumatj, North-East Arnhem Land); Paddy Bedford (Gija, East Kimberley); Ningura Napurrula (Pintupi, Gibson Desert, Northern Territory); and Tommy Watson (Pitjantjatjara, Gibson Desert, Western Australia); and a superb glass installation by Judy Watson (Waanyi, Northwest Queensland). All of these were executed by the architectural firm Cracknell and Lonergan (Price 2007, 133). Alas, for the ordinary visitor these can only be seen from the road, although they are still alluringly beautiful, especially as illuminated at night.

In the gift shop the ceiling is adorned with a mural inspired by bark painting designed by John Mawurndjul (figure 6), while a column was painted by him in situ in the style of a "hollow log." A photo series by the late Michael Riley reflecting on Indigenous Australian Christianity is installed on the wall facing the Rue de l'Université. Photographs by New Zealand's Michael Parekowhai and Fiona Pardington are reproduced on the walls facing the garden on the Seine side (Naumann 2006, I 20). It is clear from films of the opening ceremonies that not only were French and foreign visitors moved by these contemporary artworks by Indigenous Australians, but those three artists who accepted the proffered first-class tickets to Paris were also moved. ${ }^{27}$ Gulumbu Yunupingu was moved to tears when she saw her painting of "weeping stars" blown up and reproduced on a ceiling, but she insisted these were tears of happiness. Besides the gift of her art, she proclaimed that she was leaving three things in Paris: past, present, and future (Marcom Projects 2008).

Other Indigenous Australians were less convinced. Respected curator Djon Mundine acknowledged that Indigenous Australians were now more visible, but still primarily as "primitives" rather than "first peoples" (Marcom Projects 2008). ${ }^{28}$ And the diplomatic harmony, the mutual celebration between France and Australia, and the media hype glossed over the tough 


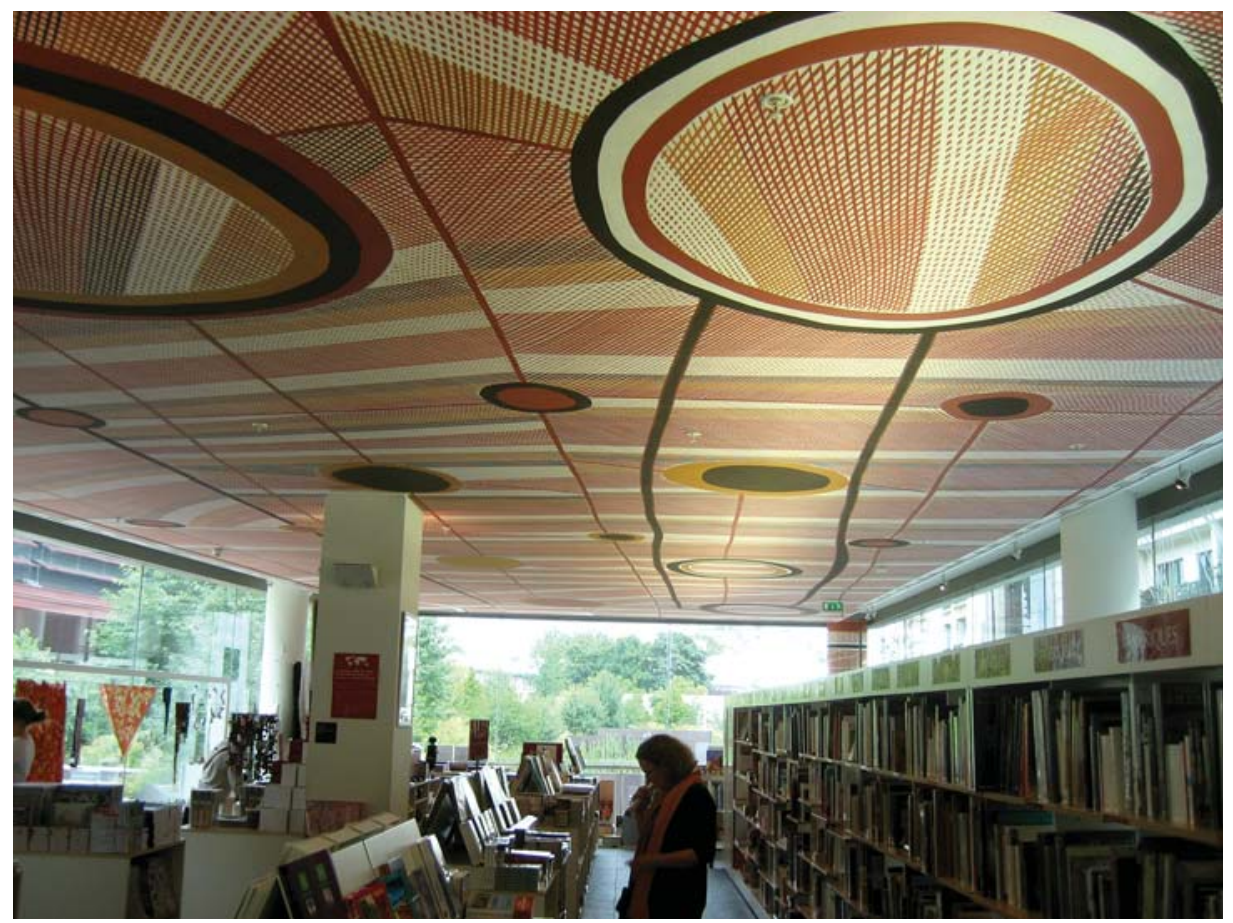

FIGURE 6. Ceiling in MQв gift shop inspired by bark painting by John Mawurndjul, Indigenous Australian artist. 15 June 2008. Photo courtesy of Geoffrey White.

content of much of the Indigenous Australian art, which exposed the violence of both nations' colonial histories. Paddy Bedford's original offering reflected on a massacre in 1920 by white landowner Paddy Quilty, who poisoned five Aborigines; ${ }^{29}$ Michael Riley's photographs are critical of the way in which Christianity eclipsed Indigenous spirituality; and Judy Watson's ceiling evokes the impact of French nuclear testing in the Pacific. ${ }^{30}$

These critical concerns were amplified for me when I saw the display of Kupka's collection at one end of the plateau des collections. I had spent a long time in "Melanesia," with its strong focus on male initiations and sacred sculptures (see Jolly nd), and in "Polynesia," admiring cases on tattooing and body arts, Māori tiki and other taonga, and some tapa textiles. I then arrived in "Australia," where I was shocked to see twenty bark paintings in a tiny room, massed on walls, jostling each other for space in a curious simulacrum of a style of display used in many nineteenth-century European art galleries. I moved on to the shimmering innovations of 


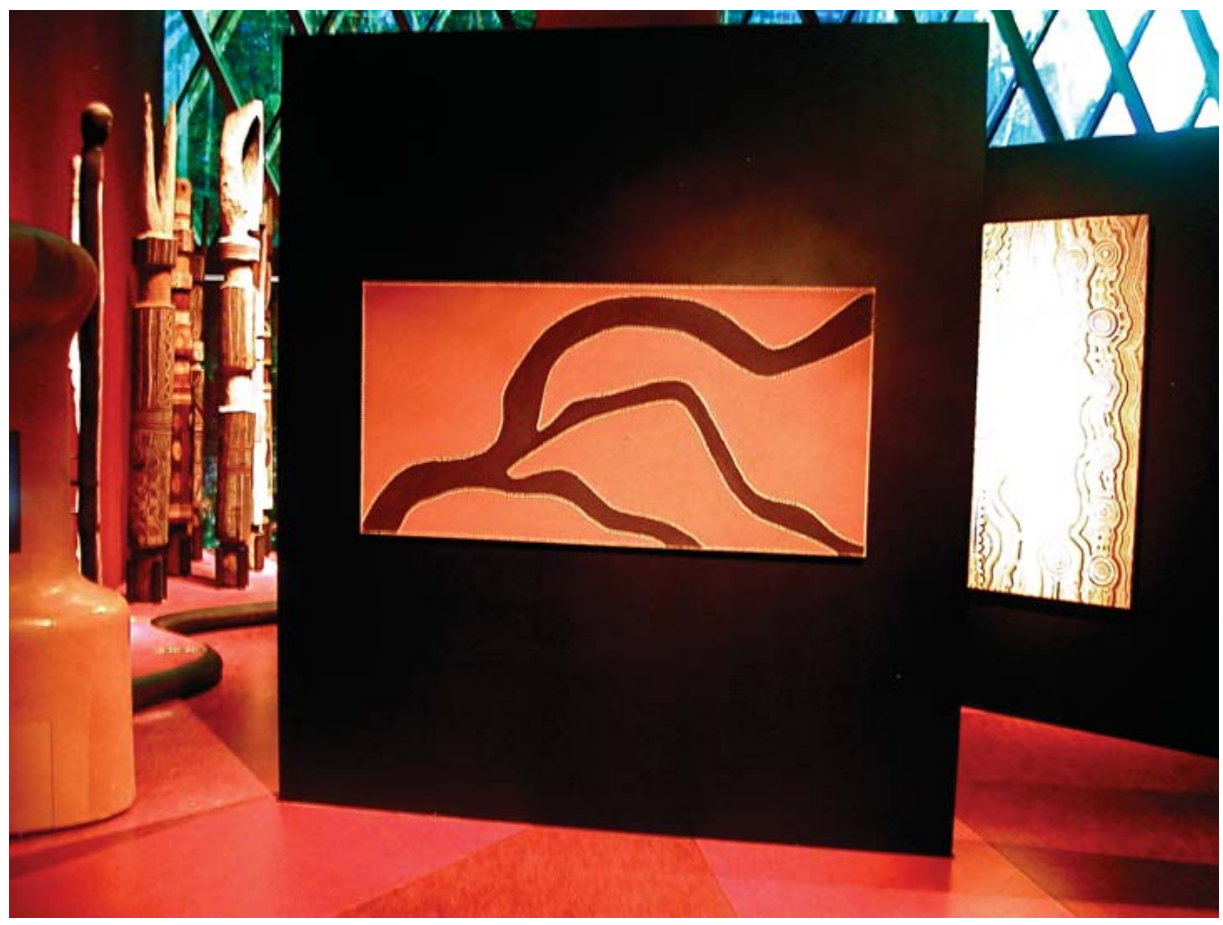

Figure 7. Painting titled Ord River, Bow River, Denham River, by Rover Thomas, Indigenous Australian artist, in Australian section of MQB permanent collection. June 2006. Photo courtesy of James Clifford.

acrylic dot paintings from twentieth-century desert artists, largely devoid of their historical context in the Papunya Tula movement (although that is offered in the museum guide; see Myers I998, 2005b). Finally, I came to Rover Thomas's stunning canvases, too easily viewed through the lens of modernist abstraction, leaving viewers unaware of their caustic and painful commentary on Australian colonial massacres (Price 2007; Thomas I996; see figure 7).

The inclusion of Indigenous Australian art in the very fabric of Nouvel's building and in the permanent collection raises intriguing but unsettling questions. Was it easier for France to deal with "others" dissociated from their own colonial past? (See Naumann 2006; Naumann interview in Marcom Projects 2008; Sauvage 2007.) But what then of those objects from Africa and the islands of Oceania, which bring with them the more specific hauntings of France's own colonialism? Stéphane Martin suggested that the museum has attracted a very different audience from the Louvre 
or the Pompidou Centre, a younger and more multicultural crowd, including presumably many migrants from France's former colonies in Africa (Naumann 2006; this is supported by Shelton 2009, I4). In interviews with Caroline Brothers published in the New York Times in 2006, this was affirmed by immigrants from Senegal and Algeria: "This museum, it's the proof that this culture is being taken into account" (Amadou AchardSy, originally from Senegal); "we are not used to seeing things from the Maghreb in a museum" (Kahina Boudaa, whose parents are Algerian immigrants). Brothers's headline proclaims "Immigrants Flock Proudly to Musée du Quai Branly," yet several of her interlocutors spoke not just of pride or nostalgia for "home" but of pain and sadness at seeing the spoils of French colonialism: "Whether for beauty, value or curiosity, all of the objects that belonged to us and to our ancestors were pillaged" (Khady Senghor, who runs a gallery for African art in Dakar); "on the African continent there is nothing left ... everything that was a treasure can be found in this museum" (Fato Bidaye, an architectural designer from Senegal, living in Tunis). And the cruel paradox of France opening a museum that celebrates the stunning beauty of African objects in French collections, simultaneous with Sarkozy threatening to expel unwanted African immigrants (see note II), was not lost on some. Aminata Traoré, Mali's former minister of culture, "penned a scathing denunciation [of] the fact that people from the cultures represented ... would never have a chance to see the creativity of their own heritage" (Price 2007, I 5 I).

So Chirac's new museum on the Seine is not so new. It promotes a postcolonial rhetoric of the universal equality of peoples through the equality of arts. Yet its canons of beauty and its conceptions of "art" are overwhelmingly Eurocentric. The elevation of these works as "masterpieces" owes more to their value for modernist European artists like Picasso and subsequent collectors like Kercharche than it does to any reevaluation of non-Western meanings, aesthetic canons, or the efficacy of non-Western "art" objects. Thus I found there not a truce in the war between aesthetic and ethnographic approaches to the objects (as Chirac had proclaimed in opening the Louvre gallery in 200I), but rather the celebrated triumph of the former. ${ }^{31}$ Stéphane Martin and many of the MQB curators have declared this war of polarities to be boring and passé (see Shelton 2009, IO, I2). And it is, since the ethnographic and the aesthetic can be consummately combined, as many exhibitions have attested. ${ }^{32}$ But in the context of debates about $\mathrm{MQB}$, the complicity of ethnography with colonialism is overplayed, while the colonial character of "primitivism" in modern 
art is forgiven, even forgotten (see Price 1989). The stress on beautiful, enigmatic objects like the alluring ecology of a manufactured "state of nature" keeps others at a distance. It occludes the deep historical connections between France and its colonies, in the history of the moving objects on display and in the peoples-citizens, immigrants, tourists-who circulate around the glass cases. If cultures are talking at Musée du Quai Branly, it appears that only certain people are party to those conversations and empowered to talk. As Kanak scholar and Tjibaou Cultural Centre Director Emmanuel Kasarherou expressed it at the opening events, "You should not imagine that by putting our objects into your museum you're letting us be the ones to talk about them" (quoted in Price 2007, I76).

\section{Pacific Encounters Comes to Quai Branly: Hosting Oceanic Dialogues}

Yet, two years after its opening, in June 2008, the Musée du Quai Branly hosted an event where Oceanic peoples, museum directors, curators, scholars, and artists had much to say. This was a two-day symposium, "Exhibiting Polynesia: Past, Present and Future," convened by Steven Hooper and Karen Jacobs in association with the opening of the temporary exhibition Polynésie: Arts et Divinités 1760-I860, which they first curated and displayed at the Sainsbury Centre for Visual Arts in Norwich in 2006 as Pacific Encounters: Art and Divinity in Polynesia I760-I860. Stéphane Martin, recently returned from a Pacific Islands Museums Association conference in Port Vila in May 2008, opened the event and on that occasion articulated a far more collaborative approach, not only with the Sainsbury Centre but also with Oceanic peoples and curators.

Alongside curators from the Smithsonian, the British Museum, and the Cambridge University Museum of Archaeology and Anthropology (Adrienne Kaeppler, Jenny Newell, and Amiria Salmond), there was strong representation from Aotearoa/New Zealand, from Hawai'i, and two curators from French Polynesia (but, given the Polynesian focus, none from New Caledonia). Arapata Hakiwai from Wellington gave the keynote address on representing Māori in Te Papa Tongarewa. He saw the bicultural values and protocols of this museum, which draw on the Treaty of Waitangi, evidenced in the achievements of the last decade: how Te Papa has engaged Māori not just as spectators but also as participants through the creation of a living marae in the museum and through the acknowledgment of their rights as descendants of the creators of the taonga to access 
the objects and to reanimate their mauri (life force) through reconnections to living cultures. As well as those permanent collections that aspire to tell a more national narrative, every two and a half years exhibitions by particular iwi are mounted that tell their more specific histories through objects. For these, Te Papa acts as facilitator. Hakiwai explained how Te Papa has assisted in the revitalization of certain practices, for instance, the Matariki, the Māori New Year, which celebrates the celestial return of the Pleaides. He stressed how the worth and efficacy of a new museum lies not in the richness of its collection but in its relationships.

In a subsequent presentation, Sean Mallon spoke of his work as Pacific Islander curator at Te Papa, celebrating an "Island Nation" and how the recent reinstallation in the Pacific Halls represents Islanders as insiders in New Zealand, not as exotic outsiders. The precontact genealogical connection of Māori and Pacific Islanders is now stressed, as is their colonial historical connection, through the relation of Māori to the iconic figure of Tupaia (on Cook's first voyage) and through later nineteenth century sojourns by Tahitian laborers and ni-Vanuatu mission students. Mallon highlighted the installation inspired by Katerina Teaiwa's profoundly relational history of phosphate connecting Islanders and New Zealanders: as the deposits moved from Banaba and Nauru, leaving those places denuded and dessicated, they greened the fields and pastures of New Zealand (see Teaiwa 2002, 2005). Mallon also stressed how his curatorial practice is directed not so much toward the beautiful objects of an art museum but toward ordinary things: rugby mementoes, T-shirts, hats made of bread bags, the costumes of the Pacific Sisters, and hip-hop CDs. The aesthetics of the new installation look stunning, but Islander visitors to Te Papa are typically not overawed by the more pristine, ancient objects; rather, Mallon has heard some say, "I have a better one at home."

Like Hakiwai, Mallon observed how the democratization of the new museum's relationships with its constituent communities has meant far more work for curators. This was also highlighted in a presentation by Fuli Pereira from the Auckland Museum, who elaborated on the challenges in her own practice, on the "harsh and humbling lessons" of her successive attempts to engage Islanders through advisory groups. Many advisors were at first bewildered and cautious because of a lack of any preexisting relation to the museum, and they suggested they had too much to do already to do more unpaid work. It took years to build up relationships of trust, but ultimately the Pacific galleries opened to positive responses in I999. The Pacific Pathways exhibition in 200I, which brought women 
textile artists into the space of the museum, and Vaka Moana in 2006, which explored Oceanic voyaging, were both very successful. ${ }^{33}$ Ultimately, benign disinterest transmuted into warm engagement with the museum on the part of Pacific communities in Auckland.

Presentations from Tahitian and Hawaiian participants in Paris suggested how divergent geopolitical situations create profound differences in the cultural politics around Oceanic collections. Jean Marc Pambrun, speaking for Manouche Lehartel, spoke of how Polynesia was displayed in contemporary festivals in French Polynesia, while Tara Hiquily asked whether the relations among Polynesians, their objects, and their ancestors irretrievably evinced a "broken link" given the ruptures created by colonialism and the impositions of the foreign views of explorers, missionaries, and ethnographers. Most of the objects found in the museum in Tahiti are those of greatest tapu: human remains, images of gods, and the prestigious possessions of chiefs. They were placed in the museum as they had been previously in caves to safeguard their mana, to save them from being burnt, drowned, mutilated by converts, or taken "home" by missionaries.

Presentations from the large contingent from Hawai' $i$, from both the Bishop Museum and the University of Hawai'i at Mānoa, were potent and poignant. Noelle Kahanu spoke of the refurbishment of the Hawaiian Hall at the Bishop Museum as the realization of an ancient prophecy, and of how the three levels are being conceptualized as heaven, people, and sea. Hawaiian scholars, cultural practitioners, and contemporary artists were also involved in the process of renovation, with a central message that their culture not only existed in the past as represented by the historical artifacts but is also alive and dynamic today.

This kind of persistence is evoked by Kū, not just as the god of war but also as a pan-Hawaiian icon of what it is to stand and be upright $(\mathrm{k} \overline{\mathrm{u}})$, to continue, to procreate, and to prosper after the overthrow of the Hawaiian kingdom in I893. Both Noelle Kahanu and Lilikalā Kame'eleihiwa wept as they spoke of the simultaneous pleasure and pain they felt on communing with Ku in the MQB exhibition, as their presence reanimated the god's mana, or power, in the image. Kame'eleihiwa imagined the prospect that all the Kù in overseas museums or, as Kahanu expressed it, his present "temples"-Göttingen, Peabody, and the Bishop - might one day be reunited in Hawaici. ${ }^{34}$ But, she said, it would be too hard if they returned only to depart again. The difference from other speakers was marked: Hawaiians passionately articulated a desire for the material repatriation 
of these objects-subjects, not just their virtual electronic repatriation while they remained overseas. This visceral connection to $\mathrm{Ku}-$ the joy, anger, and grief he can evoke in Hawaiians-surely connects to the difficult, seemingly insurmountable struggles that the Hawaiian sovereignty movement faces in the last state of the United States of America.

Their geopolitical situation differs dramatically not just from those Oceanic peoples in independent nations like Tonga or Vanuatu but also from those in settler colonies like Aotearoa/New Zealand where the relations of colonialism have been partially redressed through bicultural and multicultural practices. Hakiwai more comfortably acknowledged the large number of Māori taonga in metropolitan museums as "cultural ambassadors." So Te Papa has, after long consultation with the particular iwi linked with the marae/meeting house in the Field Museum in Chicago, resolved to leave it there. It is, Hakiwai said, "their custodian of choice." Yet clearly Māori were not so comfortable with the eight Māori heads still held in Musée du Quai Branly. They were requested back in 2008 but denied by then Minister for Culture Christine Albanel, with recourse to French arguments about their particular responsibility to safeguard "universal patrimony." ${ }^{35}$ Subsequently, as the new minister for culture, Frédéric Mitterrand reversed this policy, and on 30 June 2009 a bill approving the repatriation of all Māori heads in French collections was unanimously passed by the upper house of the French Senate (see The Age 2009). In May 20I0, the French National Assembly approved this legislation (see The Guardian Weekly 2010).

Relations between Oceanic peoples and Oceanic collections are being transformed not only in those countries with large Pacific populations but in other metropolitan museums as well, despite the difficulties caused by geographical and cultural distance. Within Europe Britain has been at the forefront in this regard, most notably through the Melanesian Project and exhibitions at the British Museum and the Cambridge University Museum. The Melanesia Project at the British Museum, led by Lissant Bolton and Nicholas Thomas, aimed to connect the objects in the collection with Indigenous narratives and to explore questions of ownership, heritage, and "relations between museums and communities." ${ }^{36}$ It also encouraged creative interactions with the collections or reflections on the project, as in the painting by Ralph Regenvanu, created during his residency of several months in 2006, which adorns not just the website of the Vanuatu Cultural Centre but also the cover of an issue of this journal in 2007 (volume 19, number 2). 
Diasporic New Zealand artists in Britain have been engaged to perform in conjunction with exhibitions at several British museums over the last few years and have brought fun and tough humor to these events. At the MQв symposium in June 2008, Rosanna Raymond and George Nuku performed and reflected on their past performances in London, Norwich, Cambridge, and elsewhere. As Raymond suggested, embodied performances in museums evince the "living dynamism of Polynesian cultures ... transforming otherwise static displays, bringing forth real power and taboo" (2008, 286; emphasis in original). In the "salon lecture de Jacques Kercharche," Raymond read her sensuous, satiric poetry and exposed some of the tensions in articulating art with education programs, in funding performance art, and in the security concerns of major museums. She told a hilarious story of how she was challenged by a security guard in the British Museum during the showing of Power and Taboo with the words: "If you want to be spontaneous in future, write to me first." George Nuku showed slides of his extraordinary polystyrene marae exhibited in Cambridge and spoke of the dual challenges of working with poor and homeless youth and of being a "plastic Māori." The plasticity of his postcolonial performance art was especially prominent in slides of his shows at the Captain Cook Birthplace Museum in Middlesbrough, UK: with full body tattoo and facial moko, George dressed up in replicas of Cook's uniform, consummately masquerading as "the captain."

The "Exhibiting Polynesia" conference in June 2008 and the robust dialogue between curators across Oceania that emerged there perhaps suggest that $\mathrm{MQB}$ is now opening more space to Pacific people to converse with and alongside the objects created by their ancestors and to debate the role of museums as custodians, of Oceanic objects as "cultural ambassadors," and the contexts where material rather than virtual repatriation is sought. And yet the conference, like the exhibition, was orchestrated by British curators, and most presentations were in English; senior MQB staff were there only for the opening, while only two or three curators were present throughout. How far the voices heard in that basement conference room will resonate in the broader spaces of the institutional and material structures of the $\mathrm{MQB}$, only time will tell. But my cautious optimism might prove justified and is, it seems, shared by other commentators.

Recently, Price discerned a broadening of MQB's vision in the "impressive range of scheduled events" and the vigor and diversity of the temporary exhibitions, despite the continuing "basic problems" of the permanent exhibition spaces (20I0, I2). Shelton was similarly damning of the per- 
manent exhibitions: "While highlighting the objects, the darkness defines an absence radiant with older prejudices and presuppositions about these objects that is quite at odds with the institution's commitment toward vanquishing any hierarchy between the world's artistic traditions and aesthetic sensibilities." He agreed that there are still "no native voices or colonial history in the quai Branly." But he too evinced hope, again concentrated in the vast temporary exhibition spaces, of a more open intercultural perspective and the prospect of including more contemporary art. He suggested that the inherent contradiction between the MQB's different agendas may yet deliver a "very different kind of institution than Chirac and Kercharche ever intended," even "a very unique institution that might yet challenge some of our most dearly held museological presuppositions" (Shelton $\left.2009,7, \mathrm{I}_{3}, 9, \mathrm{I} 4\right) .{ }^{37}$ So, Clifford's 2007 analysis was surely prescient in foreseeing that a thick tangle of "contradictions and tensions" would be exposed at the Musée du Quai Branly, and in suggesting that its future should not be summarily foreclosed.

\section{How New Is the New Museum?}

How, then, might we situate Musée du Quai Branly in broader contemporary conversations about the "new museum"? (See Message 2006.) The "newness" claimed for the new museum is far more than recent creation or renovation. Some suggest that new museums reside in a novel cultural and political terrain, with newly configured, even "postcolonial" relations between creators, collectors, objects, curators, and spectators. These allegedly eclipse the earlier colonial character of Enlightenment knowledge, preoccupied as it was with distantiated classification and presumptuous evolutionary typologies of "others" and the objects they created. Some think that this has been superseded by more open and dialogical relations of knowing, more interactive collaborations, more egalitarian curatorial postures, and more embodied performances linked to exhibitions. This claim bears critical scrutiny in its representation of pasts, presents, and futures (see MacDonald 2007).

The rhetoric about the "new" museum and especially about novel postcolonial relations remains just that, if it is not translated into the hard work of daily institutional practice. In my several visits to Musée du Quai Branly in 2008-2009, I observed rather the expanding spotlight of a Western aesthetic that left ethnography and history in the dark. Moreover, as Emmanuel Kasarherou has lamented, the voices of Pacific peoples 
were excluded by the opening curatorial practices of Quai Branly. Yet, as we have seen, on the occasion of the "Exhibiting Polynesia" conference and the associated Polynésie exhibition in June 2008, Pacific voices were heard inside the museum, in deep conversation and robust debate. Perhaps the curators of the "new" museums of Aotearoa/New Zealand, Hawai'i, French Polynesia, New Caledonia, Vanuatu, and even the United Kingdom might, through future collaborations, help to ensure that France is better articulated with broader global debates and ongoing transformations in museum practice. That might generate conversations not between reified "cultures" but between living, embodied people. Revealing the real treasures of Oceanic collections means reconnecting these objects-subjects with living Pacific persons in all their diversity in Island and diasporic communities, their refractory differences and their contending views, their claims for special access to museums and influence over curatorial strategies, and even on occasion their loud, indignant calls for the physical repatriation of objects and especially human remains. In the case of the Māori heads, such calls have finally elicited a positive response from France. Announcing the return of those heads, French Minister of Culture Frédéric Mitterrand proclaimed: "You do not build a culture on trafficking. You build a culture on respect and on exchange" (The Guardian Weekly 20I0). As Arapata Hakiwai has affirmed, the worth and efficacy of "new" museums resides not so much in the wealth of their collections but in the richness of human relationships they engender and nurture.

THIS PAPER IS BASED on several visits to the MQB in June 2008 and February, March, and July 2009. During my first week at the museum I was fortunate to attend the opening of the exhibition Polynésie: Arts et Divinités I760-1860 and the associated symposium "Exhibiting Polynesia," and to discuss this essay with Lorenzo Brutti, Sally Price, and Jim Clifford. I thank them for their generous conversations. I also thank Robert Foster for his reading of this text originally as part of a longer keynote lecture delivered at the European Society for Oceanists (ESfO) conference in Verona in July 2008, "Moving Objects: Reflections on Oceanic Collections." I followed his editorial suggestion that given that lecture's length it should be published as a separate paper. I thank the organizers of the Esfo conference Dr Anna Paini and Dr Elisabette Gnecchi-Ruscone for their approval of this publication strategy. This version of the paper was submitted to THE CONTEMPORARY PACIFIC in October 2009, and revised and updated in April, June, and October 20I0. Warm thanks to Michelle Antoinette for her excellent proofreading and comments on the first version, Chris Ballard for his reflections and bibliographic 
suggestions, and the two reviewers for The Contemporary Pacific for their cogent and constructive comments and excellent suggestions, not all of which I have been able to effect in the time available. I thank Geoff White and Jim Clifford for permission to publish their photos. I thank several people at the University of Melbourne where I delivered this talk on 2 September 20Io, in particular Chris Healy, Ghassan Hage, and Emma Koval. Finally, heartfelt thanks to Jan Rensel for her meticulous and creative work as a copy editor. My research and writing in 2008-10 has been variously funded by the Australian National University, the Australian Research Council, Centre National Recherche Scientifique (CNRS), and École des Hautes Études en Sciences Sociales (EHESS).

\section{Notes}

I I have, following Sally Price's convention, chosen to capitalize the title of the museum and other French museums in English even though they are often lowercased in French. I also use its acronym, мQв.

2 Anthony Alan Shelton is the director of the Museum of Anthropology and a professor in the Department of Anthropology at the University of British Columbia.

3 This was not an unprecedented desire. In I909 Guillaume Appollinaire argued, "To date works of art from Australia, Easter Island, New Caledonia, New Hebrides, Tahiti, the various regions of Africa, Madagascar, etc. have hardly been shown except in ethnographic collections, where they serve as curiosities and documents, thrown in pell-mell with the most vulgar, ordinary objects and the natural products of their regions. The Louvre should take in certain exotic masterpieces whose effect is no less moving than that of beautiful specimens of Western culture" (quoted in Price 2007, 34).

4 The continued existence of Pavillon des Sessions is uncertain. Although the guidebook claims it stands as a "permanent 'branch"” of Musée du Quai Branly "more than it foreshadows it" (MQB 2006, 296), in other contexts MQB Président Stéphane Martin has given it fifteen years.

5 See the huge debate that ensued after the exhibition and associated book (Rubin I984).

6 Price's book includes a superb account of the "cohabitation" between anthropologists and museum directors like Germaine Viatte and Stéphane Martin with far more "aesthetic agendas" (Price 2007, 48ff).

7 See the reference to the cannibalizing of the other museums in the description of Paris Primitive on the website of Richard Price and Sally Price (http:// www.richandsally.net/paris_primitive__jacques_chirac_s_museum_on_the_quai _branly_62 I88.htm [accessed 6 May 2008]). Sally Price stressed that the reconfiguration not only involved these two preexisting museums but also had broader 
ramifications across Parisian and national museums (2007, 23-47, 8 I-I IO). The staff of the preexisting museums also strongly resisted the reconfiguration.

8 Shelton offered a telling appraisal of the decades-long crisis of the Musée de l'Homme and observed the cruel irony of its mounting, in 2006, an exhibition on birth, in which the galleries designed to emulate "dreary mid century hospital wards" were nearly empty of visitors (2009, I 2, 2).

9 The artifacts are stored below the flood level of the Seine and although they are allegedly protected from inundations from the river and the sewers, Jean Guiart and others have expressed doubts (Clifford 2007, 7). In a session at the Esfo meeting in Verona in July 2008, Philippe Peltier (MQB senior curator for the Pacific and Insular Southeast Asia) acknowledged that many objects are held on trolleys that can be wheeled to higher levels if flood threatens, while very large objects are stored off site.

Io I do not have space to detail the debates about the repatriation of human remains here. Whereas many remains, including those of Indigenous Australians, have been repatriated from British, American, and other European museums, the French state was earlier resisting similar pressures. It has however dramatically changed its policy in the last two years. Marcellin Abong, director of the Vanuatu Cultural Centre, has recently requested the return of some rambaramp effigies (Matthew Spriggs, pers comm, I 8 September 20I0).

I I Violent demonstrations of young unemployed, including immigrants, erupted in Clichy-sur-Bois in September 2005, then spread to the center of Paris and across France. For a discussion of Sarkozy's tough policies on migrants, see Price 2007, I 27-I 28, 2 I0.

I 2 As Chris Healy has reminded me, a universalist frame can be detected in anglophone museums, such as the Britisn Museum in London, but I suggest the French form is distinctive.

I 3 In June 2008 a new temporary exhibition opened at $\mathrm{MQB}$, entitled Planète Métisse: To Mix or Not to Mix? This explored racial, cultural, and aesthetic métissage (mixing). This contrasted starkly with the predominant emphasis in the permanent collection on the purity of ancient and unfamiliar objects and the vast differences among regions of the world: Africa, the Americas, Asia-and Oceania, partitioned as Melanesia, Polynesia, Micronesia, Australia. The history of cultural connections, exchange, and mixing among these regions is muted, as is that between Europe and these regions, which have been created and essentialized as part of Europe's imperial cartographic imagination (see Jolly 2007 on Oceania; White nd).

I4 Shelton expressed a rather more generous view of the structure and Nouvel's vision: he saw the mélange of architectural styles working against monumentality and the complex works more as a zone where diverse buildings nestle in landscape. Nouvel proclaimed that he had built around the collection, with the objects in view (Shelton 2009, 2-4). Although he had twenty-five collaborators 
on the project, the power resided with Nouvel, MQB Président Stéphane Martin, and Jacques Chirac, when he was president of France. Curators have complained of architectural constraints on their exhibitions, enshrined by the terms of Nouvel's contract until 20I2 (Price 20I0, I4). Nouvel designed the glass display cases and dictated the dark palette of the galleries housing the permanent collections. Price reported that Steven Hooper, curator of Polynésie: Arts et Divinités $I 760-I 860$ (which opened at MQB in June 2008), in his desire to emphasize light and openness, wanted to paint a black column white in the temporary mezzanine gallery, but Nouvel denied that request (Price 2010, I 5 ).

I 5 Although I deploy Price's satiric label, derived from its depiction as le mur poilu in an MQB publication (Price 2007, 209n2), I acknowledge the serious intent in Nouvel's attempt to develop "green" buildings. Still, the difficulties of reconciling gardens on walls with museum storage and conservation are apparent. The estimated I 5,000 plants rooted on the hydroponic wall by the designer Patrick Blanc require much close attention and have allegedly caused excessive humidity in the administrative offices behind (Shelton 2009, 4). The gardens designed by Gilles Clément cover 7,500 square meters and have been variously likened to a jungle, a "garden of Eden," Rousseau's state of nature, and a "sacred grove," echoing James Frazer's The Golden Bough of I 890 (Shelton 2009, 6-7).

I 6 I found it more like a pedestrian freeway and was uncomfortable at the prospect of stepping on the faces of people projected on the floor. Perhaps others were similarly discomfited, since Price reported that the video installation at the entrance has since been dismantled and "visitors now trek up the 520-foot ramp in unbroken white silence" (20IO, II). Subsequently, a new artwork was installed. She also noted how over the course of three years many more lightbulbs have been introduced, obscure labels replaced, and missing names of some artists and sculptors added. Like other commentators, she praised the lecture series, performances, and vigorous temporary exhibition program (averaging ten per year) on wide-ranging topics.

I7 Kimmelman's review is scathing: “an enormous, rambling, crepuscular cavern that tries to evoke a journey into the jungle, downriver, where suddenly scary masks or totem poles loom out from the darkness and everything is meant to be foreign and exotic" $(2006,3)$.

I 8 Nouvel also called this channel a "serpent"; it has been widely lampooned as an aesthetic embarrassment that "elevates a clunky failure of taste into an error of judgment" (Harding 2007, 32).

I9 Price detailed the extraordinary process whereby each object from the other two museums was cleaned of mold and insects, disinfected, and, if damaged, repaired before being digitally photographed (2007, I I6-I I 8 ).

20 I have retained the spelling of the original quote; the accented German should read Natürvölker.

2 I "If the Marx Brothers designed a museum for dark people, they might 
have come up with the permanent-collection galleries: devised as a spooky jungle, red and black and murky, the objects in it chosen and arranged with hardly any discernible logic, the place is briefly thrilling, as spectacle, but brow-slappingly wrongheaded. Colonialism of a bygone era is replaced by a whole new French brand of condescension" (Kimmelman 2006, 3).

22 See Shelton's observations about how the buildings and gardens allude to two Rousseaus: Jean-Jacques Rousseau and his vision of an original state of nature and the "Parisian junglescapes" of Douanier Rousseau (Shelton 2009, 7).

23 Though one MQB curator dismissed Price's 2007 book as “journalism," I found it impressively lucid and accessible. It was clearly written at pace, and although less theoretically inflected than her superb Primitive Art in Civilized Places (1989), its thesis is cognate. Like Fred Myers, whose blurb appears on the cover, I relished the deft lightness of tone and the telling anecdotes therein. White has provided a compelling appraisal of Price's book and of how MQB has been a "lightning rod for commentary and controversy" (White nd). White's unpublished essay offers a critical meditation on the essentialized and bounded regions of culture and civilization, and the color-coded taxonomies of the Africas, Americas, Asia, and Oceania at MQв.

24 Beyond the seminal role of Jacques Kercharche, in her 20 Io article in Museum Anthropology Price noted the extraordinary influence of collectors and dealers in the formation of мQв. They are far more concerned with the history of an object once it has moved from its original context of creation and circulation into the hands of collectors and dealers; this is crucial to its pedigree and market value. Further, as Price pointed out, collectors and dealers are not disinterested parties. In this article she told the disturbing story of Djennenke, the striking androgynous statue from Mali that stands at the opening to the permanent exhibition spaces (Price 2010, I 5-16).

25 The project was endorsed by diplomatic exchanges between Chirac and John Howard, then prime minister of Australia, and both the Australian government and private foundations gave generously to MQв. It was directed by two Indigenous Australian curators, Brenda Croft and Hetti Perkins, in collaboration with Philippe Peltier. They selected art that was representative and that did not perpetuate stereotypes of Indigenous Australians. Nouvel's idea of reproducing small, hand-painted artworks as large decorations on the ceilings and walls of the building was a huge challenge for the architectural firm Cracknell and Lonergan (Price 2007, I33). In discussions in a session at the Esfo meeting in July 2008, MQв Senior Curator Philippe Peltier suggested that this was a way of honoring great artists, as in the European tradition of ceiling decorations. Price lamented that the biographies of the Indigenous Australian artists were not originally included in MQв catalogues and website, perhaps because the French distinguish strongly between works that are displayed in museum galleries and works that are part of museum buildings. In her view, this might explain but does not justify the 
lack of full, online biographies of these artists, an omission that has only recently been partially redressed (Price 2010, I7).

26 Price wrote that when the artist refused to sign off she was threatened with severance from the project (2007, I39).

27 Unlike the Indigenous people who were showcased at the Colonial Exposition in I93 I, this time the artists were not on display as exotic examples of evolutionary inferiority; instead, their performances embodied the equal dignity of Indigenous Australian culture. The installation of photographs by Michael Riley, who died before the opening, was seen by Indigenous Australians as transforming the museum into a spiritual place; songs and ceremonies affirmed a bond of human kinship with the French, through the gift of Indigenous creativity to this new museum (Marcom Projects 2008).

28 Clifford has opened the large gap between notions of "first arts" and "first peoples" (2007, I9), noting how Chirac's rhetoric in his inaugural address spoke of "ces peoples, dits 'premiers" (these peoples, called "first")—hardly a rousing affirmation of Indigenous claims.

29 Since this painting did not conform to the space available on the building, images from two of Bedford's paintings were amalgamated, a controversial decision that arguably transgressed his rights as an artist (Price 2007, I39).

30 Price trenchantly critiqued how the description of the artists' work inscribed on the wall of the building (reproduced in translation in Price 2007, I34-I35) tends to downplay the critique of the violence of colonialism in several works, relegating Indigenous Australians to an ethnographic niche populated by "fig trees, sacred sites, ancestral power, secret ceremonies, rock holes ... and the billabong at Mukkamukka. . . . Set next to condemnations of massacres, French nuclear tests, and the forced suppression of native religions, politically correct mentions of 'a poignant memorial to the systematic dispossession of Indigenous people and their culture' and 'a recurring symbol of resistance and survival' come across as flaccid euphemisms” (Price 2007, I39).

3 I Chirac asserted, "The conflict between the so-called 'aesthetic' and 'ethnographic approaches' no longer applies” (200I, 9).

32 Shelton adjudged that some of MQB's temporary exhibitions "went behind the old and immensely futile contrasts between anthropological contextualization and aesthetic approaches to recognize both as valid methodologies, but methodologies that are themselves implicated within modernist discourses and themselves reconstitutive of any idealized originating context"; they fulfilled the museum's “double vision” (2009, I 2). White was more pessimistic in his assessment of claims by MQB's defenders that the "art/ethnography opposition is a false dichotomy." He suggested that the "lingering ambiguity of an art museum that defines its identity in geocultural terms (Africa, Asia, Oceania, Americas) means that the discourses of art and ethnology were fated to co-mingle in ways that prove to be endlessly ambiguous and contentious" and that "the process of 
planning and construction continually ran up against these dualisms, rooted in discursive practices that are much larger than the Quai Branly" (White nd, 8).

33 The Vaka Moana exhibition appropriately traveled and was at the National Museum of Australia in Canberra from 5 June to I 5 October 2009.

34 This reunification subsequently happened, if temporarily; the three $\mathrm{Ku}$ images were displayed together in the Hawaiian Hall at the Bishop Museum from 5 June-4 October 2010.

35 In fact the museum in Rouen and the mayor of Rouen decided to repatriate some mummified and tattooed Māori heads in their collection as atonement for colonial wrongs but were prevented from doing so in 2008 by Albanel and a court ruling. The complexities of the legal situation were critically discussed at a Centre National de la Recherche Scientifique (National Center for Scientific Research) conference in Rochefort, during a panel on 29 May 2008 at which I was present. A previous symposium on human remains in museums had been held at MQB in February 2008.

36 Of course this was quite a challenge at such a distance. But generous funding brought several visitors to London from Papua New Guinea (Samuel Luguna, Trobriands); Solomon Islands (Rev Ikan Rove, Kenneth Roga, Salome Samou); and Vanuatu (Ralph Regenvanu), and supported Liz Bonshek as a postdoctoral fellow and Rebecca Jewell as artist in residence. The British Museum collections are vast but "largely unstudied" and the project aimed not only to increase knowledge but also to disseminate that knowledge, not just through scholarly genres but also through radio programs and print media to source communities in Oceania. More theoretical aims were also articulated: the project aspired to "assess approaches to art in anthropology, aiming to move beyond the current stand-off between meaning-oriented perspectives and those building on Gell's theory of 'art as agency,' while acknowledging the continuing usefulness of both these paradigms" (British Museum nd). It also supported a large conference on "Art and History in the Solomons" in October 2006 in association with the University of Bergen. This attracted about sixty delegates, including eleven from the Solomons.

37 Shelton even saw the fracture between aesthetic and ethnographic approaches as being potentially fertile- "redolent with promise" if approached critically-and suggested that, paradoxically, the passionate public debates between the two positions “may be one of the Museum's enduring legacies” (2009, I2, II).

\section{References}

The Age [Melbourne daily newspaper]

2009 French Govt Backs Return of Maori Heads. The Age, 30 June. Online at http://news.theage.com.au/breaking-news-world/french-govt-backs -return-of-maori-heads-20090630-d2rh.html [accessed 6 July 2009] 
Armstrong, Claire, editor

2006 Australian Indigenous Art Commission/Commande Publique d'Art Aborigène: Musée du Quai Branly. Paddington, Nsw: Art and Australia Pty Ltd.

British Museum

nd Melanesian Art: Objects, Narratives and Indigenous Owners. British Museum website: http://www.britishmuseum.org/research/research _projects/melanesia_project.aspx [accessed 6 September 2008]

Brothers, Caroline

2006 Immigrants Flock Proudly to Musée du Quai Branly. New York Times, 2 I August. http://www.nytimes.com/2006/08/2 I/arts/design/2 Imuse .html [accessed 6 May 2008]

Brutti, Lorenzo

2003 L'ethnologie est-elle soluble dans l'art premier? Essai de lecture ethnographique du Musée du quai Branly par le regard d'un observateur participant. In L'esthétique: Europe, Chine et ailleurs, edited by Yolaine Escande and Jean-Marie Schaeffer, I3-36. Paris: You-Fang.

Chirac, Jacques

200I Preface. In Sculptures: Africa, Asia, Oceania, Americas, edited by Jacques Kerchache, 8-9. Paris: Réunion des musées nationaux, Musée du Quai Branly.

2007 Quai Branly in Process. October I 20 (Spring): 3-23. Republished in edited form in Le Débat I 47:29-39.

Digard, Jean-Pierre

2008 Musée du quai Branly: Dialogue des cultures ou monologue? L'Homme I-2 (I 85-I 86): 449-453.

Dupaigne, Bernard

2006 Le scandale des arts premiers: La véritable histoire du musée du quai Branly. Paris: Mille et une nuits.

Godelier, Maurice

2009 Excursus: Combining the Pleasures of Art and Knowledge for the Museumgoing Publics. In In and Out of the West: Reconstructing Anthropology, I77-I9I. Charlottesville: University of Virginia Press.

The Guardian Weekly [Manchester news digest]

20I0 France Returns Maori Heads. The Guardian Weekly, I4 May, Io.

Harding, Jeremy

2007 At Quai Branly: Jeremy Harding on Jacques Chirac's Museum. London Review of Books 29 (I): 32-33 (4 January). Online at http://www .lrb.co.uk/v29/nor/jeremy-harding/at-quai-branly [accessed Io September 20IO] 
Hooper, Steven

2006 Pacific Encounters: Art and Divinity in Polynesia I760-I860. Norwich, uk: Sainsbury Centre for Visual Arts and British Museum Press.

Jolly, Margaret

2007 Imagining Oceania: Indigenous and Foreign Representations of a Sea of Islands. The Contemporary Pacific I9:508-545.

nd Material and Immaterial Relations: Gender, Rank and Christianity in North Vanuatu. In The Scope of Anthropology, edited by Laurent Dousset and Serge Tcherkézoff. Oxford: Berghahn, forthcoming.

Kimmelman, Michael

2006 A Heart of Darkness in a City of Light. New York Times, 2 July. Online at http://travel2.nytimes.com/2006/07/02/arts/design/o2kimm.html [accessed 6 May 2008]

Lebovics, Herman

2009 Will the Musée du Quai Branly Show France the Way to Postcoloniality? African and Black Diaspora 2 (2): 23 I-244.

Le Débat

2007 Le moment du Quai Branly. Special issue of the bimonthly journal Le Débat I 47 (Nov-Dec).

MacDonald, Sharon

2007 Review of New Museums and the Making of Culture, by Kylie Message. reCollections, Journal of the National Museum of Australia 2 (2). Online at http://recollections.nma.gov.au/issues/vol_2_no2/book _reviews/new_museums_and_the_making_of_culture/ [accessed $6 \mathrm{May}$ 2008]

Marcom Projects

2008 Museum of the World. Documentary DVD, two parts, 52 minutes each.

Part I: Farewell Primitive, directed by Michelle Viotte. Part 2: Songlines to the Seine, directed by Julie Nimmo. sBs Documentaries, distributed through Marcom Projects, 2. [screened on SBs Television, Australia, 30 May and 6 June 2008].

Message, Kylie

2006 New Museums and the Making of Culture. Oxford: Berg.

MQB, Musée du Quai Branly

2006 Museum Guide Book (English edition). Paris: Musée du Quai Branly. Myers, Fred

I998 Uncertain Regard: An Exhibition of Aboriginal Art in France. Ethnos 63 (I): $7-47$.

2005 a "Primitivism," Anthropology, and the Category of "Primitive Art." In Handbook of Material Culture, edited by Chris Tilley, Webb Keane, 
Susanne Kuechler, Michael Rowlands, and Patricia Spyer, 267-284. London: Sage Press.

2005b Collecting Aboriginal Art in the Australian Nation: Two Case Studies. Visual Anthropology Review 2I (I-2): I I6-I37.

Naumann, Peter, editor

2006 Making a Museum: “it is making theater, not writing theory." An Interview with Stéphane Martin, Président-directeur general, Musée du quai Branly. Museum Anthropology 29 (2): I I 8-I 27.

Ouroussoff, Nicolai

2006 For a New Paris Museum, Jean Nouvel Creates His Own Rules. New York Times, 27 June. Online at http://www.nytimes.com/2006/06/27/ arts/design/27bran.html [accessed 6 May 2008]

Price, Sally

I989 Primitive Art in Civilized Places. Second edition. Chicago: University of Chicago Press.

2005 Art and the Civilizing Mission. Anthropology and Humanism 30 (2): I33-I 40.

2007 Paris Primitive: Jacques Chirac's Museum on the Quai Branly. Chicago: University of Chicago Press.

20I0 Return to the Quai Branly. Museum Anthropology 33 (I): I I-2 I.

Raymond, Rosanna

2008 Review of Power and Taboo, Pasifika Styles and Pacific Encounters. The Contemporary Pacific 20:283-286.

Rubin, William S, editor

I984 "Primitivism" in 2oth Century Art: Affinity of the Tribal and the Modern. New York: Museum of Modern Art.

Sauvage, Alexandra

2007 Narratives of Colonisation: The Musée du Quai Branly in Context. reCollections: Journal of the National Museum of Australia 2 (2): I35I 52 .

Shelton, Anthony Alan

2009 The Public Sphere as Wilderness: Le Musée du Quai Branly. Museum

Teaiwa, Katerina Anthropology 32 (I): I-I6.

2002 Visualizing te Kainga, Dancing te Kainga: History and Culture between Rabi, Banaba and Beyond. PhD dissertation, The Australian National University.

2005 Our Sea of Phosphate: The Diaspora of Ocean Island. In Indigenous Diasporas and Dislocations: Unsettling Western Fixations, edited by Graham Harvey and Charles D Thompson Jr, I69-190. London: Ashgate Press. 
Thomas, Nicholas

I996 Cold Fusion. American Anthropologist 98 (I): 9-25.

White, Geoffrey

nd Civilizations on the Seine: Sally Price's Paris Primitive. Manuscript. Copy in author's files.

\section{Abstract}

The Musée du Quai Branly (MQв) has been the focus of passionate debates in scholarly and public media in France and globally, since even before its opening in June 2006. These debates have often polarized advocates of divergent aesthetic and ethnographic approaches to museum practice, although some argue this is a false dichotomy and that the MQв has the future potential to realize a "double vision." Yet both approaches have their discursive origins in EuroAmerican scholarship and museological practice, and effecting a genuinely "double vision" must surely confront the question of the relation of objects in museums and galleries to living peoples and especially the descendants of the creators of such objects/ subjects. This essay explores this question in relation to MQв displays of Oceanic art, in particular the Pacific and Indigenous Australian art in the permanent collections and in the fabric of Jean Nouvel's building. It juxtaposes the museum's credo "where cultures converse" with the voices of Oceanic curators in dialogue at a conference held in association with the Polynésie exhibition in June 2008. It suggests that becoming a "new museum" is predicated not just on the rhetoric of an equality of arts, but also on people becoming engaged in more respectful relations of dialogue and exchange.

KEYWORDs: museums, Oceanic art, Indigenous Australia, France, aesthetics, ethnography, repatriation 